\title{
Lutein as a functional ingredient in sheep milk yogurt: development, characterization and extraction recovery
}

\author{
Raphael Ferreira de BARROS ${ }^{1 \star}$ (D), Fernanda Romano TORRES ${ }^{1}$, Paulo Henrique Fonseca da SILVA², \\ Paulo Cesar STRINGHETA³, João Pablo Fortes PEREIRA², Junio Cesar Jacinto de PAULA ${ }^{4}$, \\ Camila Sampaio CUTRIM ${ }^{5}$, Marco Antonio Sloboda CORTEZ ${ }^{1}$
}

\begin{abstract}
The research aimed to evaluate the behavior of different concentrations of lutein added in sheep milk yogurt. The work verified the effect on acidity, $\mathrm{pH}$, color, lutein degradation, and recovery during storage. Different added lutein concentration into yogurt were compared: $0.00 \mathrm{mg} ; 3.0 \mathrm{mg} ; 3.45 \mathrm{mg}$; and $3.9 \mathrm{mg}\left(\cdot 100 \mathrm{~mL}^{-1}\right)$. Analyzes were performed on days $1^{\text {st }}, 15^{\text {th }}, 30^{\text {th }}$, and $45^{\text {th }}$ of refrigerated storage $\left(5^{\circ} \mathrm{C}\right)$. Lutein did not influence fermentation patters, but post acidification was observed, mainly in groups with the highest lutein concentrations. The amount of lutein recovered was different between groups $(\mathrm{P}<0.05)$ due to treatment. Some differences $(\mathrm{P}<0.05)$ in the same treatment occurred over time, tending to decrease lutein recovery. For all treatments, up to the end of storage, the final amount of lutein characterized the product as a nutritional source of this element. However, lutein recovery in $\mathrm{G} 4$ has reached the minimum daily intake recommended by researchers for health benefits. Recovery ranged from $81.9 \pm 0.76 \cdot 100^{-1}\left(\mathrm{w} \cdot \mathrm{w}^{-1}\right)$ to $76.31 \pm 1.07 \cdot 100^{-1}\left(\mathrm{w} \cdot \mathrm{w}^{-1}\right)$ on the storage period. $\mathrm{L}^{\star}$ has no difference $(\mathrm{P}>0.05)$ between groups with different added lutein concentrations. In contrast, $\mathrm{a}^{*}, \mathrm{~b}^{*}, \mathrm{c}^{*}$, and $\mathrm{YI}$ (yellowness index) were different $(\mathrm{P}<0.05)$.
\end{abstract}

Keywords: carotenoids; antioxidant; yogurt; sheep milk; fermentation.

Practical Application: Sheep milk yogurt with lutein provides nutritional and functional appeals.

\section{Introduction}

The dairy industry is concerned about developing new high nutritive products to meet the consumers' demand for food enriched in carotenoids and other vitamins and provitamins (Fusaro et al., 2019; Renes et al., 2018). Most consumers much appreciate yogurt over other dairy products because of their sensory properties and higher digestibility than milk (Cruz et al., 2017a).

Furthermore, nutritional value and sensory quality of yogurt are also influenced by milk chemical composition (Kaminarides et al., 2007; Yildiz-Akgul, 2018; Yildiz \& Ozcan, 2019). Yogurt manufacture using sheep milk is an exciting approach because of the improvement in nutritional value between other species (Balthazar et al., 2017; Park et al., 2007).

Ovine milk has higher contents of protein, lipids, minerals, and vitamins essential to human health compared with caprine and bovine milk (Barlowska et al., 2011; Kaminarides et al., 2007; Park et al., 2007). Moreover, the structure of sheep milk proteins has smaller micelles and with different partition micellar types than those of cow milk. This fact suggests that both casein and whey proteins in sheep milk can be a useful, convenient alternative for those who are allergic to cow milk (Masoodi \& Shafi, 2010).
Kaminarides et al. (2007) and Park et al. (2007) highlight that, beyond the proteins, the sheep milk is more abundant than cow and goat milk in fat, ashes, calcium, iron, manganese, phosphorus, zinc, medium-chain fatty acids, monounsaturated fatty acids, linolenic acid (CLA), all essential amino acids and most of the vitamins. For this reason, sheep milk has high biological value high digestibility, alkalinity, and is hypoallergenic. Thus, yogurt made with sheep milk consequently presents, from a nutritional point of view, beneficial health effects.

Lutein (LT) is a yellow-pigmented macular carotenoid which is an excellent antioxidant that prevents tissues from free radical damages. It interferes with the free radical formation and kidnaps reactive oxygen species (Alves Rodrigues \& Shao, 2004; Johnson, 2014; Shami \& Moreira, 2004). Also, it protects photoreceptors by filtering out the incidence of high energy blue light, harmful to the macula. A decrease of visual sensitivity in older people with low macular pigment density in the eyes tissues could be the precursor of some eye diseases, including Age-Related Macular Degeneration (AMD) (Johnson, 2014; Madaan et al., 2017; Stringheta et al., 2006). In addition to evidence of a reduced risk of AMD developing, among many beneficial effects can be highlighted the protection against atherosclerosis, cataracts,

${ }^{1}$ Departamento de Alimentos, Faculdade de Veterinária, Universidade Federal Fluminense - UFF, Niterói, RJ, Brasil

${ }^{2}$ Departamento de Nutrição, Instituto de Ciências Biológicas, Universidade Federal de Juiz de Fora - UFJF, Juiz de Fora, MG, Brasil

${ }^{3}$ Departamento de Tecnologia de Alimentos, Centro de Ciências Exatas e Tecnológicas, Universidade Federal de Viçosa - UFV, Viçosa, MG, Brasil

${ }^{4}$ Empresa de Pesquisa Agropecuária de Minas Gerais - EPAMIG, Juiz de Fora, MG, Brasil

${ }^{5}$ Núcleo Avançado de Tecnologia de Alimentos e Gestão de Cooperativismo - NATA, São Gonçalo, RJ, Brasil

*Corresponding author: raphaelfbarros@veterinario.med.br 
cancer and other diseases (Alves Rodrigues \& Shao, 2004; Chasan-Taber et al., 1999; Deli et al., 2004; Krinsky \& Johnson, 2005; Tokusoglu, 2013; Madaan et al., 2017; Stringheta et al., 2006; Sumantran et al., 2000).

Hammond et al. (1997) demonstrate through their studies that an increased intake of LT generally responds with higher concentrations of these carotenoids in blood serum and maculae. Lutein is found in green leafy vegetables, especially dark leafy such as spinach, kale, watercress, and broccoli (Rodriguez-Amaya, 2001). Since the human body cannot synthesize carotenoids, a balanced diet with the consumption of foods rich in these compounds is required (Stringheta et al., 2006). In addition Wang et al. (2018) demonstrate that lutein content of milk was affect by dietary supplementation of the cows' diet with lutein and antioxidant as Vitamin E, tea polyphenols and ethoxyquin..

The research aimed to evaluate the behavior of different concentrations of lutein added in yogurt manufactured from sheep milk. The study also assessed the effect of lutein on acidity, $\mathrm{pH}$, color, lutein carotenoid degradation, and recovery by spectrophotometer during the storage period, as well as sheep milk characterization.

\section{Materials and methods}

All experiment was repeated three times, besides each analysis has been done at least three times as well. All laboratory analyses were carried out with artificial lights off, in low natural light, to avoid lutein degradation.

\subsection{Sheep milk as raw material}

Sheep milk was collected from the dairy farm and transported at a temperature between $4{ }^{\circ} \mathrm{C}$ and $5{ }^{\circ} \mathrm{C}$, to be processed in a pilot-scale dairy factory.

Milk composition and physicochemical properties were analyzed according to Association of Official Analytical Chemists (2012). It was performed triplicate analysis of acidity by titrimetric method (AOAC Official Method 947.05); $\mathrm{pH}$ by using a pH probe (pH-meter PG1800, CapLab, São Paulo, Brazil) (AOAC Official Method 973.41); specific gravity at $15.0^{\circ} \mathrm{C}$ by termohigrometer method (AOAC Official Method 925.22); solids (total) (AOAC Official Method 925.23); total nitrogen, obtaining the total protein percentage by multiplying the nitrogen percentage by 6.38 (AOAC Official Method 991.20); nonprotein nitrogen (AOAC Official Method 991.21); lipids (AOAC Official Method 2000.18) and ashes (AOAC Official Method 945.46).

Furthermore, non-fat solids were calculated subtracting the total fat $(\mathrm{w} / \mathrm{w})$ from total solids $(\mathrm{w} / \mathrm{w})$, and the approximately total carbohydrates were calculated subtracting all components from total solids (w/w).

\subsection{Yogurt culture}

Thermophilic lactic acid cultures DVS YC-X11 (Chr. Hansen Laboratories, Denmark), were used at the dosage of 50U in 500L of milk, following the supplier's instructions. Still, the culture was diluted to $500 \mathrm{~mL}$ sterile milk in controlled aseptic conditions, to obtain $10^{11} \mathrm{CFU}$ per gram of inoculum.

\subsection{Yogurt and samples preparation}

Yogurts were made applying the traditional method (Barros et al., 2019; Tamine \& Robinson, 2007). The process was modified, as described in Figure 1.

Initially, raw sheep milk was filtered and heat-treated at $90^{\circ} \mathrm{C} \pm 2{ }^{\circ} \mathrm{C}$ for five minutes in a Stainless steel double jacketed boiling vat with stirring, followed by cooling to $42^{\circ} \mathrm{C} \pm 1{ }^{\circ} \mathrm{C}$.

Treated milk was divided into four different stainless steel fermentation vats, corresponding to the four experimental groups to prepare the yogurt. First, lutein (LT) was added individually in each vat and homogenized. After that, following the same precautions, one milliliter of the inoculum was added for each $1000 \mathrm{~mL}$ of the mixture, reaching a count of $10^{8} \mathrm{CFU} \cdot \mathrm{mL}^{-1}$ in the product to initiate the milk fermentation process at $42^{\circ} \mathrm{C} \pm 1{ }^{\circ} \mathrm{C}$, until fermented milk reached pH 4.8 (after approximately a 4 hours incubation).

Upon to achieve the stopping point (ph 4.8), yogurt was stirred (after the fermentation period), and the samples were bottled into opaque $200 \mathrm{~mL}$ polyethylene bottles and refrigerated at $5^{\circ} \mathrm{C}$. Four groups (treatments) were formed with different added FloraGLO ${ }^{\circledR}$ Lutein 5\% CWS/S-TG (E161b*) (DSMNutritional Products, Switzerland) concentrations: group 1 (G1): no FloraGLO ${ }^{\circledR}$ added in milk; group 2 (G2): 0.6 mg of FloraGLO ${ }^{\circledR}$ per mL of milk; group $3(\mathrm{G} 3)$ : $0.69 \mathrm{mg}$ of FloraGLO ${ }^{\circledR}$ per mL of milk; and group 4 (G4) $0.78 \mathrm{mg}$ of FloraGLO ${ }^{\circledR}$ per $\mathrm{mL}$ of milk. The final concentration of the inoculum in the final product was: $0.00 \mathrm{mg}$ of LT.100 $\mathrm{mL}^{-1}$; $3.0 \mathrm{mg}$ of LT. $100 \mathrm{~mL}^{-1}$; $3.45 \mathrm{mg}$ of LT. $100 \mathrm{~mL}^{-1}$; and $3.9 \mathrm{mg}$ of LT $100 \mathrm{~mL}^{-1}$, respectively (considering FloraGLO ${ }^{\circledR}$ Lutein five percent purity).

\subsection{Physicochemical analyses of yogurt}

After twenty-four hours of cooling (day 1), post-manufacture, yogurt composition, and physicochemical properties were determined in triplicate according to Association of Official

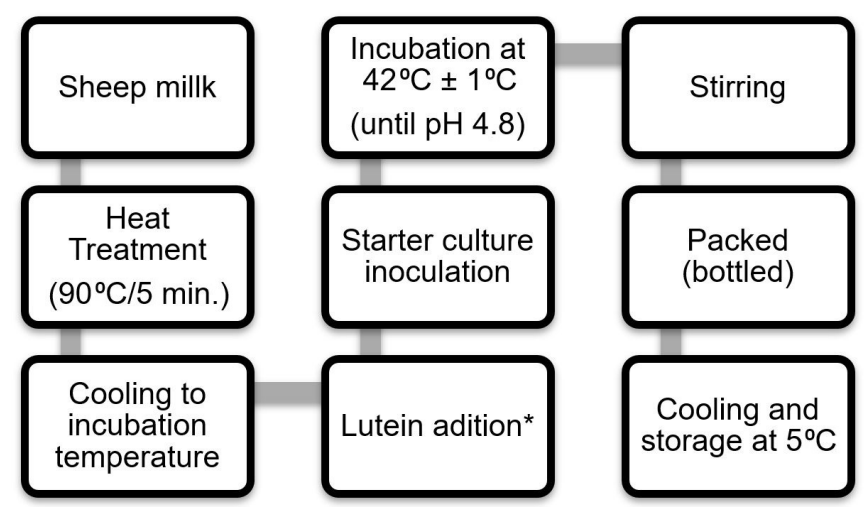

Figure 1. Flow chart of yogurt production from sheep milk with different lutein contents. The experiment was performed in triplicate. ${ }^{\star} \mathrm{G} 1: 0.00 \mathrm{mg} \cdot 100 \mathrm{~mL}^{-1}$ of lutein added; G2: $3.0 \mathrm{mg} \cdot 100 \mathrm{~mL}^{-1}$ of lutein added; G3: $3.45 \mathrm{mg} \cdot 100 \mathrm{~mL}^{-1}$ of lutein added; G4: $3.9 \mathrm{mg} \cdot 100 \mathrm{~mL}^{-1}$ of lutein added. 
Analytical Chemists (2012) (acidity, pH, specific gravity, total solids, total nitrogen, nonprotein nitrogen, and ashes). Furthermore, solids not-fat were calculated subtracting fat $\left(\mathrm{w} \cdot \mathrm{w}^{-1}\right)$ from total solids $\left(\mathrm{w} \cdot \mathrm{w}^{-1}\right)$. The approximately total carbohydrates were calculated subtracting all components from total solids $\left(\mathrm{w} \cdot \mathrm{w}^{-1}\right)$. Acidity and $\mathrm{pH}$ analysis were also assessed in triplicate during the product shelf life, on days $1^{\text {st }}, 15^{\text {th }}, 30^{\text {th }}$ and $45^{\text {th }}$, of storage at refrigeration temperature.

\subsection{Color determination}

Color analyses were carried out using a portable measurement instrument CR-400 Croma Meter (Konica-Minolta, USA), previously calibrated with $\mathrm{Y}=94.2 ; \mathrm{x}=0.3160 ; \mathrm{y}=0.3326$ standard white plate. Color measurements were determined based on the CIELAB coordinates $\left(\mathrm{L}^{*}, \mathrm{a}^{*}, \mathrm{~b}^{*}\right)$, assessing two-color coordinates, $\mathrm{a}^{\star}$ and $\mathrm{b}^{\star}$, and the psychometric index of lightness, $\mathrm{L}^{*}$. The parameter $\mathrm{a}^{\star}$ displays positive values for reddish colors, and negative values for the greenish ones. The parameter $b^{\star}$ displays positive values for yellowish colors, and negative values for the bluish ones. $L^{*}$ is an approximate measurement of the luminosity. Hue $\left(h^{*}\right)$ and saturation $\left(c^{*}\right)$ parameters were calculated from $\mathrm{a}^{\star}$ and $\mathrm{b}^{\star}$ values, according to Equations 1 and 2, respectively. Yellowness Index (YI) parameter was calculated according to Equation 3, respectively (Pathare et al., 2013; Vargas et al., 2008). Three readings for each sample were recorded. The equipment was inserted one centimeter into the yogurt sample to perform the analyses.

$$
\begin{aligned}
& h^{*}=\tan ^{-1}\left(\frac{b^{*}}{a^{*}}\right) \\
& c^{*}=\sqrt{a^{*^{2}+b^{* 2}}} \\
& Y I=\frac{142.86 b^{*}}{L^{*}}
\end{aligned}
$$

\subsection{Extraction and quantification of lutein}

The extraction of the lutein was performed in triplicate on the days $1^{\text {st }}, 15^{\text {th }}, 30^{\text {th }}$ and $45^{\text {th }}$, of storage at refrigeration temperature. The protocol was adapted from Rocha et al. (2017), due to the specific characteristics of the sheep milk. Five milliliters of Ethanol $95 \cdot 100^{-1}\left(\mathrm{v} \cdot \mathrm{v}^{-1}\right)($ Synth) were added to $5 \mathrm{~g}$ of each sample and then centrifuged at $2500 \mathrm{~g}$-force for five minutes. The supernatant was reserved, and another $5 \mathrm{~mL}$ of ethanol $95 \cdot 100^{-1}\left(\mathrm{v} \cdot \mathrm{v}^{-1}\right)$ was added to the precipitate and centrifuged. This procedure was repeated four more times. Then, the same procedure was repeated once with $5 \mathrm{~mL}$ of Acetone (Synth), and the supernatant also reserved. The extraction was performed by adding $50 \mathrm{~mL}$ of acetone to the total supernatant, stirring for one minute, and transferring to a separatory funnel containing $60 \mathrm{~mL}$ of Petroleum Ether (Synth). The mixture of ethanol, acetone, LT, and petroleum ether was washed successively with distilled water. The mixture of LT and ether obtained by separatory funnel was collected in a $250 \mathrm{~mL}$ round-bottom flask and dried on vacuum rotary evaporator (Tecnal TE-210, Brazil) at $40^{\circ} \mathrm{C}$, then re-suspended in $25 \mathrm{~mL}$ (G1 samples) and $75 \mathrm{~mL}$ (G2, G3, and G4 samples) of $99.8 \cdot 100^{-1}$ Absolute Ethanol (Synth). Carotenoid content was determined by Thermo Scientific ${ }^{\mathrm{TM}}$ Evolution 60S UV-Visible spectrophotometer (Thermo Scientific) at $445 \mathrm{~nm}$, corresponding to the wavelength of maximum absorption for LT diluted in absolute ethanol, measured in a $1 \mathrm{~cm}$ cuvette (Rodriguez-Amaya, 2001). The molar absorption coefficient of $2550 \cdot \mathrm{cm}^{-1} \cdot \mathrm{g}^{-1}$ was used, and the total carotenoid content was calculated according to the Equation 4 and 5, expressed as milligrams (mg) of LT per $100 \mathrm{~g}$ of yogurt.

$$
\begin{aligned}
& x(m g)=\frac{A \cdot y(m L) \cdot 10^{3}}{A_{l c m}^{I \%} \cdot 100} \\
& x(m g / 100 g)=\frac{x(m g)}{\text { sample }(\mathrm{g})} \cdot 100
\end{aligned}
$$

$\mathrm{X}=$ lutein content $(\mathrm{mg}) ; \mathrm{A}=$ absorbance at $445 \mathrm{~nm} ; A_{1 \mathrm{~cm}}^{1 \%}=$ molar absorptivity coefficient in absolute ethanol; $\mathrm{y}(\mathrm{mL})=$ volumetric flask volume.

Carotenoid content was determined by spectrophotometer at $445 \mathrm{~nm}$, corresponding to the wavelength of maximum absorption for LT diluted in absolute ethanol. However, the wavelength for $\beta$-carotene diluted in absolute ethanol varies between $425 \mathrm{~nm}$ and $478 \mathrm{~nm}$. The maximum absorption was at a wavelength of $450 \mathrm{~nm}$ (Rodriguez-Amaya, 2001).

\subsection{Statistical analysis}

One-way ANOVA with three replications and three repeated measures of analytical methods was used to evaluate the differences between treatments and their interactions (product composition, $\mathrm{pH}$, titratable acidity, LT content, and recovery), as well as Tukey's test. Statistical significance was set at a $95 \cdot 100^{-1}$ significance level. All analyses were performed using commercially available statistical package XLSTAT 2013.2.03 (Addinsoft, Paris, France).

\section{Results and discussion}

\subsection{Sheep milk characterization}

Table 1 displays the average results of physicochemical properties, and centesimal analyses of the main components of sheep milk used as experiment raw material. The results

\begin{tabular}{|c|c|}
\hline Composition/Properties & Sheep milk \\
\hline Total dry extract $\left(\cdot 100 \mathrm{~g}^{-1}\right)$ & $18.45 \pm 0.38$ \\
\hline Protein $\left(\cdot 100 \mathrm{~g}^{-1}\right)$ & $4.00 \pm 0.09$ \\
\hline Non-protein nitrogen $\left(\cdot 100 \mathrm{~g}^{-1}\right)$ & $0.10 \pm 0.00$ \\
\hline Fat $\left(\cdot 100 \mathrm{~g}^{-1}\right)$ & $8.8 \pm 0.00$ \\
\hline $\operatorname{Ash}\left(\cdot 100 \mathrm{~g}^{-1}\right)$ & $0.93 \pm 0.02$ \\
\hline $\operatorname{Carbs}^{\star \star}\left(\cdot 100 \mathrm{~g}^{-1}\right)$ & $4.62 \pm 0.43$ \\
\hline Density $\left(g \cdot \mathrm{mL}^{-1}\right)$ & $1.037 \pm 0.00$ \\
\hline Titrable acidity (g lactic acid $\cdot 100^{-1}$ ) & $0.25 \pm 0.01$ \\
\hline pH & $6.67 \pm 0.01$ \\
\hline
\end{tabular}
of our research agree with other studies (Cruz et al., 2017b; Park et al., 2007).

Table 1. Average of main nutrients composition and physicochemical properties of sheep milk used in the experiment.

Values represent the average of triplicate analysis of milk from three different days \pm standard deviation. ${ }^{* *}$ Carbohydrates were calculated subtracting all components from the total solids. 


\subsection{Centesimal composition of yogurt}

Table 2 displays the composition of sheep milk yogurt obtained in the experiment. Based on our results, it is possible to state that the use of different LT concentrations did not affect the composition of the final product since there was no significative difference in composition among the treatments $(\mathrm{P}>0.05)$.

\subsection{Fermentation process and lutein influence}

The fermentation process was stopped when $\mathrm{pH}$ values reached 4.8. All treatments required the same time to reach the required $\mathrm{pH}$ : four hours. However, a slight post-acidification ( $P>0.05$ ) occurred within the first twenty-four hours of cooling, as verified by the difference between the $\mathrm{pH}$ value defined as a stopping point and the $\mathrm{pH}$ observed in the following day. Yogurt culture uses lactose as energy source and converts lactose into lactic acid, lowering the $\mathrm{pH}$ values and elevating the titrable acidity (TA) values, which allows gel formation. Even at cooling temperatures, this process continues slowly (De Ancos et al., 2000; Vianna et al., 2019). Table 3 shows that one day after the conclusion of the fermenting stage of production, no difference of $\mathrm{pH}$ or TA was present among the treatments $(\mathrm{P}>0.05)$. This datum points out how LT did not affect sheep milk fermentation until this period, neither positively nor negatively. Vianna et al. (2019) studied yogurts produced with milk of different species. The authors observed that sheep milk yogurt had a higher TA. The high buffering effect of milk from ewe explains the higher TA values, thus justifying the greater impact on TA results than $\mathrm{pH}$ values obtained in the present research.

\subsection{Colorimetric determinations}

Table 3 displays the colorimetric determinations based on the CIELAB coordinates $\left(\mathrm{L}^{*}, \mathrm{a}^{*}, \mathrm{~b}^{*}\right)$. G1 Lightness $\left(\mathrm{L}^{*}\right)$ was higher than in the other treatments $(\mathrm{P}<0.05)$, confirming lighter color on treatment with no LT added. $\mathrm{L}^{*}$ values decreased in G2, G3, and G4 gradually, as LT concentration increased (Table 3). However, differences were non-significant. In contrast, there was a significant effect of LT content on $\mathrm{a}^{*}$ and $\mathrm{b}^{*}$ parameters. The values increased among treatments $(\mathrm{P}<0.05)$, following the increase in the LT level. Values were positive for $\mathrm{a}^{\star}$, tending to reddish rather than greenish, and for $b^{*}$, tending to yellowish rather than bluish. Studies performed on Prato cheese (ripened Brazilian cheese) added with different LT concentrations displayed similar results: higher $\mathrm{a}^{*}$ and $\mathrm{b}^{*}$ values at higher LT concentrations, while $\mathrm{L}^{\star}$ did not change significantly (Kubo et al., 2013; Sobral et al., 2016). Aryana et al. (2006) also report that LT did not affect $\mathrm{L}^{*}$ in their research with LT in strawberry yogurt, as well as $\mathrm{a}^{\star}$ value increase with the amount of LT. However, $\mathrm{b}^{*}$ was not significantly affected, probably influenced and hidden by the strawberry color.

The effect of LT addition on yogurt may be evidenced by the tonality, which is represented by the hue parameter $(\mathrm{h})$. An angle of $0^{\circ}$ or $360^{\circ}$ represents red hue, while angles of $90^{\circ}$ represent yellow hues, respectively (Pathare et al., 2013). Our hue values

Table 2. Centesimal composition of yogurt manufactured with different added lutein percentage.

\begin{tabular}{lrrrr}
\hline \multicolumn{1}{c}{\begin{tabular}{c} 
Characteristcs \\
\multicolumn{1}{c}{$\left(\cdot 100^{-1} ; \mathrm{w}^{-1}\right)$}
\end{tabular}} & \multicolumn{3}{c}{ Treatments } \\
\cline { 2 - 5 } $\mathrm{w}^{-1}$ & \multicolumn{1}{c}{$\mathrm{G} 1$} & $\mathrm{G} 2$ & $\mathrm{G} 3$ & $\mathrm{G} 4$ \\
\hline Total dry extract & $18.58 \pm 0.46^{\mathrm{a}}$ & $18.75 \pm 0.51^{\mathrm{a}}$ & $18.38 \pm 0.35^{\mathrm{a}}$ & $18.24 \pm 0.27^{\mathrm{a}}$ \\
Protein & $4.05 \pm 0.26^{\mathrm{a}}$ & $3.93 \pm 0.16^{\mathrm{a}}$ & $4.14 \pm 0.25^{\mathrm{a}}$ & $3.95 \pm 0.18^{\mathrm{a}}$ \\
Non-Protein nitrogen & $0.1 \pm 0.00^{\mathrm{a}}$ & $0.1 \pm 0.00^{\mathrm{a}}$ & $0.1 \pm 0.00^{\mathrm{a}}$ & $0.1 \pm 0.00^{\mathrm{a}}$ \\
Fat & $8.73 \pm 0.09^{\mathrm{a}}$ & $8.73 \pm 0.09^{\mathrm{a}}$ & $8.73 \pm 0.09^{\mathrm{a}}$ & $8.73 \pm 0.09^{\mathrm{a}}$ \\
Ash & $0.92 \pm 0.03^{\mathrm{a}}$ & $0.92 \pm 0.02^{\mathrm{a}}$ & $0.92 \pm 0.02^{\mathrm{a}}$ & $0.91 \pm 0.02^{\mathrm{a}}$ \\
Carbs $^{*}$ & $4.79 \pm 0.50^{\mathrm{a}}$ & $5.08 \pm 0.46^{\mathrm{a}}$ & $4.50 \pm 0.39^{\mathrm{a}}$ & $4.55 \pm 0.34^{\mathrm{a}}$ \\
\hline
\end{tabular}

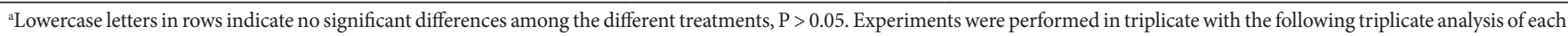
yogurt. Values represent the average of nine analyses performed \pm standard deviation. G1: $0.00 \mathrm{mg} \cdot 100 \mathrm{~mL}^{-1}$ of lutein added; $\mathrm{G} 2: 3.0 \mathrm{mg} \cdot 100 \mathrm{~mL}{ }^{-1}$ of lutein added; G3: $3.45 \mathrm{mg} \cdot 100 \mathrm{~mL} \mathrm{~L}^{-1}$ of lutein added; G4: $3.9 \mathrm{mg} \cdot 100 \mathrm{~mL}^{-1}$ of lutein added. ${ }^{*}$ Carbohydrates were calculated subtracting all components from the total solids.

Table 3. Physicochemical and carotenoids recovery results at first-day post-fermentation (sheep milk yogurt).

\begin{tabular}{|c|c|c|c|c|}
\hline Physicochemical properties & G1 & G2 & G3 & G4 \\
\hline $\mathrm{pH}$ & $4.78 \pm 0.07^{\mathrm{a}}$ & $4.77 \pm 0.07^{\mathrm{a}}$ & $4.74 \pm 0.02^{\mathrm{a}}$ & $4.74 \pm 0.04^{a}$ \\
\hline Acidity (lactic acid g.100 ${ }^{-1}$ ) & $0.99 \pm 0.06^{\mathrm{a}}$ & $1.01 \pm 0.03^{\mathrm{a}}$ & $1.06 \pm 0.04^{\mathrm{a}}$ & $1.05 \pm 0.10^{\circ}$ \\
\hline $\mathbf{L}^{*}$ & $111.82 \pm 2.85^{\mathrm{a}}$ & $100.05 \pm 1.02^{\mathrm{b}}$ & $100.00 \pm 2.51^{\mathrm{b}}$ & $99.04 \pm 1.45^{b}$ \\
\hline $\mathbf{a}^{*}$ & $-0.09 \pm 0.08^{\mathrm{d}}$ & $4.85 \pm 0.14^{\mathrm{c}}$ & $5.33 \pm 0.27^{b}$ & $5.65 \pm 0.15^{a}$ \\
\hline $\mathbf{b}^{*}$ & $9.64 \pm 0.41^{\mathrm{d}}$ & $28.55 \pm 0.30^{c}$ & $29.80 \pm 0.95^{b}$ & $30.94 \pm 0.52^{2}$ \\
\hline $\mathbf{C}^{*}$ & $9.63 \pm 0.34^{\mathrm{d}}$ & $33.98 \pm 0.27^{c}$ & $35.82 \pm 0.91^{\mathrm{b}}$ & $37.75 \pm 0.49$ \\
\hline $\mathbf{h}^{*}$ & $90.51 \pm 0.42^{\mathrm{a}}$ & $82.14 \pm 0.14^{\mathrm{b}}$ & $81.82 \pm 0.16^{c}$ & $81.74 \pm 0.12$ \\
\hline Yellowness index (YI) & $12.31 \pm 0.25^{\mathrm{d}}$ & $40.77 \pm 0.11^{\mathrm{c}}$ & $42.56 \pm 0.30^{\mathrm{b}}$ & $44.63 \pm 0.21^{\mathrm{a}}$ \\
\hline Carotenoids / lutein $\left(\mathrm{mg} \cdot 100 \mathrm{~g}^{-1}\right)^{\star}$ & $0.02 \pm 0.01^{\mathrm{d}}$ & $2.45 \pm 0.08^{c}$ & $2.86 \pm 0.06^{\mathrm{b}}$ & $3.16 \pm 0.06^{\circ}$ \\
\hline
\end{tabular}

${ }^{\mathrm{a}-\mathrm{d}}$ Lowercase letters in rows indicate significant differences among the different treatments, $\mathrm{P}<0.05 .{ }^{*}$ Total carotenoid content was expressed in mg of lutein in $100 \mathrm{~g}$ of yogurt. The experiment was performed three times with triplicate analysis of yogurt each. Values represent the average of nine analyses performed \pm standard deviation. G1: $0.00 \mathrm{mg} \cdot 100 \mathrm{~mL}{ }^{-1}$ of lutein added; G2: $3.0 \mathrm{mg} \cdot 100 \mathrm{~mL}^{-1}$ of lutein added; G3: $3.45 \mathrm{mg} \cdot 100 \mathrm{~mL}^{-1}$ of lutein added; G4: $3.9 \mathrm{mg} \cdot 100 \mathrm{~mL}^{-1}$ of lutein added. 
results were equal or very close to $90^{\circ}$. Since from yellow hue in G1 $(h=90.51 \pm 0.42)$, the treatments slight tended towards red hue in G2 and G3 $(\mathrm{P}<0.05)$, according to the increase of LT in the product. The latter was $\mathrm{P}>0.05$ compared to $\mathrm{G} 4(\mathrm{~h}=81.74 \pm 0.12)$. The values of $\mathrm{C}^{\star}$, which represent color saturation degree and intensity, increased as LT content increased, evidencing the interference of LT in this parameter. Color intensity decreased among the treatments, from G4 to G1, with significant alterations from one treatment to the other $(\mathrm{P}<0.05)$. Kubo et al. (2013) and Sobral et al. (2016) are in agreement with our results and describe that the hue values tend to decrease with the LT concentration, starting from yellow representative values to orange representative values. On the other hand, the opposite occurred with saturation $\left(\mathrm{C}^{*}\right)$, also corroborating to our results, in which values increased with increasing LT levels in Prato cheese.

Finally, the Yellowness Index (YI) indicates the degree of yellowness and is associated with $b^{*}$ values. As $b^{*}$ increased proportionally with the increase of LT in the product $(\mathrm{P}<0.05)$, YI also presented the same behavior $(\mathrm{P}<0.05)$.

\subsection{Lutein content and recovery}

According to Park et al. (2007), Sheep milk has high concentrations of Vitamin A compared to other species, due to the higher conversion of beta carotene into vitamin $\mathrm{A}$. The recovery of carotenoid traces (Table 3 ) in the control treatment (G1) is mainly due to this compound.

Table 3 displays the average values of total carotenoids on the first day of storage (after fermentation) in G2, G3, and G4. The amount of lutein of each treatment agreed with its inclusion. LT values displayed significant differences among the treatments $(\mathrm{P}<0.05)$. The average recovery to all treatments with lutein added was $81.90 \pm 0.76 \cdot 100^{-1}$.

\subsection{Titrable acidity, $\mathrm{pH}$ and lutein recovery during the storage period}

Table 4 and Table 5 show $\mathrm{pH}$ and TA values, respectively. In general, $\mathrm{pH}$ decreased during storage $(\mathrm{P}<0.05)$. At the end of storage, yogurt with higher $\mathrm{LT}$ content displayed lower $\mathrm{pH}$ values than yogurt with lower LT content $(\mathrm{P}<0.05)$. Our data show a possible influence of LT on $\mathrm{pH}$ decrease. Further studies under the same conditions and the same lactic matrix are necessary for suspicion to be adequately confirmed.

As the acidity is less affected by the buffering effect, TA values increased during storage $(\mathrm{P}<0.05)$ in all treatments, but yogurt with higher LT contents displayed higher acidification than the other samples. Therefore, higher TA values were obtained comparing to yogurt with lower LT contents $(\mathrm{P}<0.05)$. For this reason, the same tendency of LT to influence post acidification was observed. Nevertheless, LT did not affect the characteristics of the product, suggesting the possibility to include it as a functional ingredient in the yogurt formulation.

Vianna et al. (2019) observed a significant difference in lactic acid production in sheep milk yogurt during the storage period. However, the $\mathrm{pH}$ values remained constant $(\mathrm{P}>0.05)$ while the TA values increased $(\mathrm{P}<0.05)$, which also justifies our $\mathrm{pH}$ and TA results, most likely due to the buffering effect of sheep milk. On the other hand, Aryana et al. (2006) found a $\mathrm{pH}$ reduction in strawberry yogurt during storage. Still, the research was based on cow's milk, which may have contributed to this inverse behavior. The authors also found no influence of LT on post acidification during storage, which is contrary to our results despite the particularities of the dairy matrix.

Mora-Gutierrez et al. (2018) researched the interactions between LT and the caseins isolated from bovine and caprine milk. They found LT concentrations higher in the LT-enriched emulsions prepared with caprine caseins compared with the

Table 4. $\mathrm{pH}$ determination values during 45 days of storage period.

\begin{tabular}{ccccc}
\hline Treatments & Day 1st. & Day 15th. & Day 30th. & Day 45th \\
\hline G1 & $4.78 \pm 0.07^{\mathrm{Aa}}$ & $4.51 \pm 0.01^{\mathrm{Ab}}$ & $4.43 \pm 0.01^{\mathrm{Ac}}$ & $4.32 \pm 0.05^{\mathrm{Bd}}$ \\
G2 & $4.77 \pm 0.07^{\mathrm{Aa}}$ & $4.50 \pm 0.03^{\mathrm{Ab}}$ & $4.44 \pm 0.02^{\mathrm{Abc}}$ & $4.38 \pm 0.05^{\mathrm{Ac}}$ \\
G3 & $4.74 \pm 0.01^{\mathrm{Aa}}$ & $4.41 \pm 0.02^{\mathrm{Bb}}$ & $4.39 \pm 0.04^{\mathrm{Bb}}$ & $4.35 \pm 0.02^{\mathrm{ABb}}$ \\
G4 & $4.74 \pm 0.06^{\mathrm{Aa}}$ & $4.36 \pm 0.04^{\mathrm{Bb}}$ & $4.30 \pm 0.03^{\mathrm{Cc}}$ & $4.23 \pm 0.03^{\mathrm{Cd}}$ \\
\hline
\end{tabular}

${ }^{\mathrm{a}-\mathrm{d}}$ Lowercase letters in rows indicate significant differences among different days in the treatment, $\mathrm{P}<0.05$. ${ }^{\mathrm{A}-\mathrm{D}}$ Capital letters in the columns indicate significant differences among the different treatments, $\mathrm{P}<0.05$. The experiment was performed three times with triplicate analysis of yogurt each. Values represent the average of nine analyses performed \pm standard deviation. G1: $0.00 \mathrm{mg} \cdot 100 \mathrm{~mL}^{-1}$ of lutein added; G2: $3.0 \mathrm{mg} \cdot 100 \mathrm{~mL}^{-1}$ of lutein added; G3: $3.45 \mathrm{mg} \cdot 100 \mathrm{~mL}^{-1}$ of lutein added; G4: $3.9 \mathrm{mg} \cdot 100 \mathrm{~mL}{ }^{-1}$ of lutein added.

Table 5. Titratable acidity measured values during 45 days of storage period.

\begin{tabular}{ccccc}
\hline Treatments & $\begin{array}{c}\text { Day 1st. } \\
\left(\text { mg.lactic acid } 100^{-1}\right)\end{array}$ & $\begin{array}{c}\text { Day 15th. } \\
(\text { mg.lactic acid·100 }\end{array}$ & $\begin{array}{c}\text { Day 30th. } \\
(\text { mg.lactic acid.100 }\end{array}$ & $\begin{array}{c}\text { Day 45th } \\
(\mathrm{mg} .1 \mathrm{lactic} \text { acid·100 }\end{array}$ \\
\hline G1 & $0.99 \pm 0.10^{\mathrm{Ab}}$ & $1.08 \pm 0.11^{\mathrm{Ab}}$ & $1.21 \pm 0.07^{\mathrm{Ba}}$ & $1.27 \pm 0.01^{\mathrm{Ba}}$ \\
G2 & $1.01 \pm 0.08^{\mathrm{Ab}}$ & $1.09 \pm 0.13^{\mathrm{Ab}}$ & $1.23 \pm 0.07^{\mathrm{ABa}}$ & $1.28 \pm 0.01^{\mathrm{Ba}}$ \\
G3 & $1.06 \pm 0.08^{\mathrm{Ac}}$ & $1.16 \pm 0.13^{\mathrm{Abc}}$ & $1.24 \pm 0.08^{\mathrm{ABab}}$ & $1.30 \pm 0.01^{\mathrm{ABa}}$ \\
G4 & $1.05 \pm 0.11^{\mathrm{Ac}}$ & $1.21 \pm 0.09^{\mathrm{Ab}}$ & $1.32 \pm 0.07^{\mathrm{Aab}}$ & $1.63 \pm 0.07^{\mathrm{Aa}}$ \\
\hline
\end{tabular}

\footnotetext{
${ }^{\mathrm{a}-\mathrm{d}}$ Lowercase letters in rows indicate significant differences among different days in the treatment, $\mathrm{P}<0.05 .{ }^{\mathrm{A}-\mathrm{D}}$ Capital letters in the columns indicate significant differences among the different treatments, $\mathrm{P}<0.05$. The experiment was performed three times with triplicate analysis of yogurt each. Values represent the average of nine analyses performed \pm standard deviation. G1: $0.00 \mathrm{mg} \cdot 100 \mathrm{~mL}^{-1}$ of lutein added; G2: $3.0 \mathrm{mg} \cdot 100 \mathrm{~mL}^{-1}$ of lutein added; G3: $3.45 \mathrm{mg} \cdot 100 \mathrm{~mL}^{-1}$ of lutein added; G4: $3.9 \mathrm{mg} \cdot 100 \mathrm{~mL}{ }^{-1}$ of lutein added.
} 


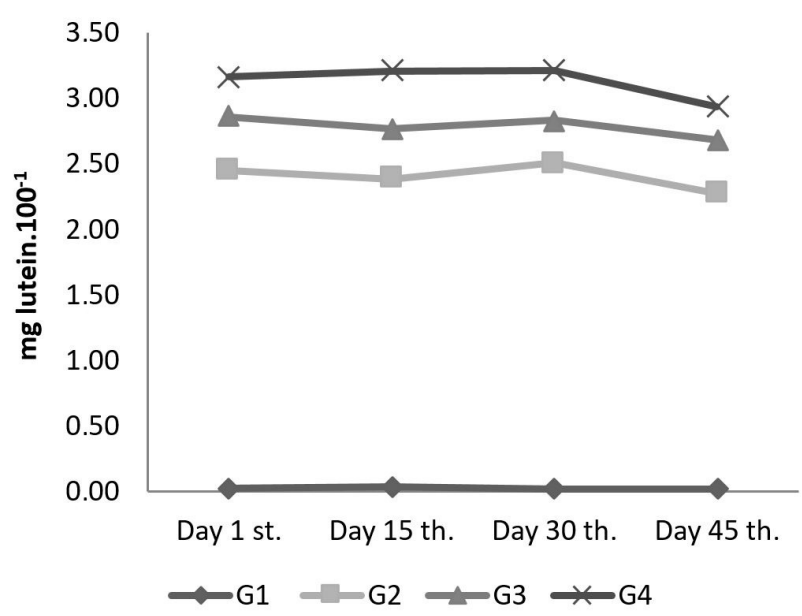

Figure 2. Treatments behavior of total carotenoids (lutein) recovery during 45 days of yogurt storage period. The experiment was performed three times with triplicate analysis of yogurt each. Values represent the average of nine analyses performed. G1: $0.00 \mathrm{mg} \cdot 100 \mathrm{~mL}^{-1}$ $\left(\mathrm{m} \cdot \mathrm{v}^{-1}\right)$ of lutein added; $\mathrm{G} 2: 3.0 \mathrm{mg} \cdot 100 \mathrm{~mL} \mathrm{~L}^{-1}\left(\mathrm{~m} \cdot \mathrm{v}^{-1}\right)$ of lutein added; $\mathrm{G} 3: 3.45 \mathrm{mg} \cdot 100 \mathrm{~mL}^{-1}\left(\mathrm{~m} \cdot \mathrm{v}^{-1}\right)$ of lutein added; G4: $3.9 \mathrm{mg} \cdot 100 \mathrm{~mL} \mathrm{~L}^{-1}\left(\mathrm{~m} \cdot \mathrm{v}^{-1}\right)$ of lutein added.

bovine casein, even during storage. Caprine and sheep milk are similar in most characteristics (Masoodi \& Shafi, 2010; Park et al., 2007). Thus, this significant interaction should also occur with sheep milk in order to contribute to previously unknown behaviors, since protein is directly related to buffer effect (Vianna et al., 2019) and also acidity (Rocha et al., 2017).

The behavior of LT recovery, as main carotenoids in sheep milk yogurt, during storage is shown in Figure 2. Except in G1 that only traces of carotenoids were recovered, probably $\beta$-carotene residues (Rodriguez-Amaya, 2001), all following treatments had recovery ranging from $81.9 \pm 0.76 \cdot 100^{-1}$ to $76.31 \pm 1.07 \cdot 100^{-1}$ throughout storage. At the beginning of storage, the recovery was higher compared to its end $(\mathrm{P}>0.05)$, showing a tendency of recovery decline over the days $(\mathrm{P}>0.05)$. At the end of storage, $\mathrm{LT}$ content was different $(\mathrm{P}<0.05)$ between each treatment. The amounts recovery were $2.3 \pm 0.01 \mathrm{mg} \mathrm{LT} \cdot 100^{-1} \mathrm{~mL}$ of yogurt in $\mathrm{G} 2,2.7 \pm 0.08 \mathrm{mg}$ $\mathrm{LT} \cdot 100^{-1} \mathrm{~mL}$ of yogurt in G3 and $3.0 \pm 0.06 \mathrm{mg} \mathrm{LT} \cdot 100^{-1} \mathrm{~mL}$ of yogurt in $\mathrm{G} 4$, which the last one reached the minimum daily intake recommended by researchers for health benefits, considering $200 \mathrm{~mL}$ per portion.

There is no official Recommended Dietary Allowance (RDA) or Recommended Daily Intake (RDI) of LT; however, the amount added was based on data indicating a $20 \mathrm{mg}$ limit as safe for daily LT consumption (Agência Nacional de Vigilância Sanitária, 2019; Shao \& Hathcock, 2006), and through studies showing the biological effects of this bioactive compound when consumed at minimal concentration of $6 \mathrm{mg}$ per day (Abdel-Aal et al., 2013; Seddon et al., 1994).

According to Aryana et al. (2006), who evaluated LT behavior into yogurt, in all treatments with different initial LT content, there was a small yet steady decline in LT content over the storage time of yogurt. A small amount of LT breakdown may explain this slight decline in LT over storage over storage time.
LT has been incorporated into many food matrices. Even the same, as LT is sensitive to heat, light, and other oxidative stressors, it is not always assured that carotenoid molecule remains intact after food processing due to the low stability outside their natural tissue. Therefore, some loss of LT in products is to be expected (Martínez-Delgado et al., 2017).

Despite all the arguments regarding the reduction of LT content recovered during storage, the amount in all treatments of the present research is considered as a functional food, aiming to increase carotenoid consumption for health benefit effects. A lutein ingredient as a functional ingredient is important to the lacteal industry as it is an option to make products commercially appealing, however further studies should be conducted focusing on additional sensory methods such as projective tests (Judacewski et al., 2019; Pinto et al., 2018) and sensory properties (Chetachukwu et al., 2019).

\section{Conclusions}

Lutein did not influence fermentation patters, but post acidification was observed, mainly in groups with the highest lutein concentrations. Lightness was not influenced by lutein concentration. However, the two-color coordinates, $\mathrm{a}^{*}$ and $\mathrm{b}^{*}$, as well as hue angle, saturation, and yellowness index, were affected by different concentrations of lutein. For all treatments, up to the end of storage, the final amount of lutein characterized the product as a nutritional source of this element. However, greater emphasis should be given to the product with $7.8 \mathrm{mg}$ of LT per portion $(200 \mathrm{~mL})$, which has reached the minimum daily intake recommended by many researchers for health benefits. Sheep's milk was an excellent product for lutein incorporation, providing a product with nutritional and functional appeal, as well as adequate visual characteristics.

\section{Acknowledgements}

Authors are grateful to the "Coordenação de Aperfeiçoamento de Pessoal de Nível Superior" (CAPES) - this study was financed in part by the CAPES - Brasil Finance Code 001, "Pró Reitoria de Pesquisa, Pós Graduação e Inovação” of Universidade Federal Fluminense (PROPPI-UFF) and veterinary medicine post-graduate program (Higiene Veterinária e Processamento Tecnológico de Produtos de Origem Animal) for financial support of this research; the "Instituto de Laticinios Candido Tostes" for allowing the manufacture of the samples in dairy pilot-scale dairy factory; the DSM Nutritional Products for supplying the commercial lutein; the Cabanha Vida farm for supplying the sheep milk; and AG Plast for supplying the polypropylene packaging.

\section{References}

Abdel-Aal, el-S. M., Akhtar, H., Zaheer, K., \& Ali, R. (2013). Dietary sources of lutein and zeaxanthin carotenoids and their role in eye health. Nutrients, 5(4), 1169-1185. http://dx.doi.org/10.3390/ nu5041169. PMid:23571649.

Agência Nacional de Vigilância Sanitária - ANVISA. (2019). Lista de ingredientes (constituintes) autorizados para uso em suplementos alimentares. Brasília. Retrieved from http://portal.anvisa.gov.br/ suplementos-alimentares/ingredientes 
Alves-Rodrigues, A., \& Shao, A. (2004). The science behind lutein. Toxicology Letters, 150(1), 57-83. http://dx.doi.org/10.1016/j. toxlet.2003.10.031. PMid:15068825.

Aryana, K. J., Barnes, H. T., Emmick, T. K., McGrew, P., \& Moser, B. (2006). Lutein is stable in strawberry yogurt and does not affect its characteristics. Journal of Food Science, 71(6), 467-472. http:// dx.doi.org/10.1111/j.1750-3841.2006.00080.x.

Association of Official Analytical Chemists - AOAC. (2012). Official methods of analysis of AOAC International (19th ed.). Gaithersburg: AOAC International.

Balthazar, C. F., Pimentel, T. C., Ferrão, L. L., Almada, C. N., Santillo, A., Albenzio, M., Mollakhalili, N., Mortazavian, A. M., Nascimento, J. S., Silva, M. C., Freitas, M. Q., Sant'Ana, A. S., Granato, D., \& Cruz, A. G. (2017). Sheep milk: physicochemical characteristics and relevance for functional food development. Comprehensive Reviews in Food Science and Food Safety, 16(2), 247-262. http:// dx.doi.org/10.1111/1541-4337.12250.

Barlowska, J., Szwajkowska, M., Litwińczuk, Z., \& Król, J. (2011). Nutritional value and technological suitability of milk from various animal species used for dairy production. Comprehensive Reviews in Food Science and Food Safety, 10(6), 291-302. http://dx.doi. org/10.1111/j.1541-4337.2011.00163.x.

Barros, R. F., Cutrim, C. S., da Costa, M. P., Conte, C. A. Jr., \& Cortez, M. A. S. (2019). Lactose hydrolysis and organic acids production in yogurt prepared with different onset temperatures of enzymatic action and fermentation. Ciência Animal Brasileira, 20, 1-10. http:// dx.doi.org/10.1590/1809-6891v20e-43549.

Chasan-Taber, L., Willett, W. C., Seddon, J. M., Stampfer, M. J., Rosner, B., Colditz, G. A., Speizer, F. E., \& Hankinson, S. E. (1999). A prospective study of carotenoid and vitamin A intakes and risk of cataract extraction in US women. The American Journal of Clinical Nutrition, 70(4), 509-516. http://dx.doi.org/10.1093/ajcn/70.4.509. PMid:10500020.

Chetachukwu, A. S., Thongraung, C., \& Yupanqui, C. T. (2019). Development of reduced-fat coconut yoghurt: physicochemical, rheological, microstructural and sensory properties. International Journal of Dairy Technology, 72(4), 524-535. http://dx.doi. org/10.1111/1471-0307.12600.

Cruz, A. G., Zacarchenco, P. B., Oliveira, C. A., \& Corassin, C. H. (2017a). Processamento de produtos lácteos: queijos, leite fermentados, bebidas lácteas, sorvete, manteiga, crème de leite, doce de leite, soro em pó e lácteos funcionais (1. ed., Cap. 6). Rio de Janeiro: Elsevier.

Cruz, A. G., Zacarchenco, P. B., Oliveira, C. A., \& Corassin, C. H. (2017b). Química, bioquímica, análise sensorial e nutrição no processamento de leite e derivados (1. ed., Cap. 9). Rio de Janeiro: Elsevier.

De Ancos, B., Pilar Cano, M., \& Gómez, R. (2000). Characteristics of stirred low-fat yoghurt as affected by high pressure. International Dairy Journal, 10(1-2), 105-111. http://dx.doi.org/10.1016/S09586946(00)00021-2.

Deli, J., Molnár, P., Osz, E., Tóth, G., \& Zsila, F. (2004). Epimerisation of lutein to 3 '-epilutein in processed foods. Bioorganic \& Medicinal Chemistry Letters, 14(4), 925-928. http://dx.doi.org/10.1016/j. bmcl.2003.12.012. PMid:15012995.

Fusaro, I., Giammarco, M., Chincarini, M., Vaintrub, M. O., Formigoni, A., Mammi, L. M. E., \& Vignola, G. (2019). Fatty acids, health indices and sensory properties of Ricotta cheese from sheep fed three different diets. International Journal of Dairy Technology, 72(3), 427-434. http://dx.doi.org/10.1111/1471-0307.12613.

Hammond, B. R. Jr., Johnson, E. J., Russell, R. M., Krinsky, N. I., Yeum, K. J., Edwards, R. B., \& Snodderly, D. M. (1997). Dietary modification of macular pigment density. Investigative Ophthalmology \& Visual Science, 38(9), 1795-1801. PMid:9286268.

Johnson, E. J. (2014). Role of lutein and zeaxanthin in visual and cognitive function throughout the lifespan. Nutrition Reviews, 72(9), 605-612. http://dx.doi.org/10.1111/nure.12133. PMid:25109868.

Judacewski, P., Los, P. R., Lima, L. S., Alberti, A., Zielinski, A. A. F., \& Nogueira, A. (2019). Perceptions of Brazilian consumers regarding white mould surface-ripened cheese using free word association. International Journal of Dairy Technology, 72(4), 585-590. http:// dx.doi.org/10.1111/1471-0307.12649.

Kaminarides, S., Stamou, P., \& Massouras, T. (2007). Comparison of the characteristics of set type yoghurt made from ovine milk of different fat content. International Journal of Food Science \& Technology, 42(9), 1019-1028. http://dx.doi.org/10.1111/j.1365-2621.2006.01320.x.

Krinsky, N. I., \& Johnson, E. J. (2005). Carotenoid actions and their relation to health and disease. Molecular Aspects of Medicine, 26(6), 459-516. http://dx.doi.org/10.1016/j.mam.2005.10.001. PMid:16309738.

Kubo, M. T. K., Maus, D., Xavier, A. A. O., Mercadante, A. Z., \& Viotto, W. H. (2013). Transference of lutein during cheese making, color stability, and sensory acceptance of Prato cheese. Food Science and Technology, 33, 81-88.

Madaan, T., Choudhary, A. N., Gyenwalee, S., Thomas, S., Mishra, H., Tariq, M., Vohora, D., \& Talegaonkar, S. (2017). Lutein, a versatile phytonutraceutical: an insight on pharmacology, therapeutic indications, challenges and recent advances in drug delivery. PharmaNutrition, 5(2), 64-75. http://dx.doi.org/10.1016/j.phanu.2017.02.005.

Martínez-Delgado, A. A., Khandual, S., \& Villanueva-Rodríguez, S. J. (2017). Chemical stability of astaxanthin integrated into a food matrix: effects of food processing and methods for preservation. Food Chemistry, 225, 23-30. http://dx.doi.org/10.1016/j.foodchem.2016.11.092. PMid:28193419.

Masoodi, T. A., \& Shafi, G. (2010). Analysis of casein alpha S1 \& S2 proteins from different mammalian species. Bioinformation, 4(9), 430-435. http://dx.doi.org/10.6026/97320630004430. PMid:20975894.

Mora-Gutierrez, A., Attaie, R., Núñez de González, M. T., Jung, Y., Woldesenbet, S., \& Marquez, S. A. (2018). Complexes of lutein with bovine and caprine caseins and their impact on lutein chemical stability in emulsion systems: effect of arabinogalactan. Journal of Dairy Science, 101(1), 18-27. http://dx.doi.org/10.3168/jds.201713105. PMid:29103708.

Park, Y. W., Juárez, M., Ramos, M., \& Haenlein, G. F. W. (2007). Physico-chemical characteristics of goat and sheep milk. Small Ruminant Research, 68(1-2), 88-113. http://dx.doi.org/10.1016/j. smallrumres.2006.09.013.

Pathare, P. B., Opara, U. L., \& Al-Said, F. A. J. (2013). Colour measurement and analysis in fresh and processed foods: a review. Food and Bioprocess Technology, 6(1), 36-60. http://dx.doi.org/10.1007/ s11947-012-0867-9.

Pinto, L. P. F., Silva, H. L. A., Kuriya, S. P., Maçaira, P. M., Cyrino Oliveira, F. L., Cruz, A. G., Esmerino, E. A., \& Freitas, M. Q. (2018). Understanding perceptions and beliefs about different types of fermented milks through the application of projective techniques: a case study using Haire's shopping list and free word association. Journal of Sensory Studies, 33(3), 1-8. http://dx.doi.org/10.1111/ joss. 12326.

Renes, E., De la Fuente, F., Fernández, D., Tornadijo, M. E., \& Fresno, J. M. (2018). Effect of feeding regimen on the fatty acid profile of sheep bulk tank milk. International Journal of Dairy Technology, 71(4), 857-867. http://dx.doi.org/10.1111/1471-0307.12553. 
Rocha, J. C. G., Mendonça, A. C., Viana, K. W. C., Maia, M. P., Carvalho, A. F., Minim, V. P. R., \& Stringheta, P. C. (2017). Beverages formulated with whey protein and added lutein. Ciência Rural, 47(3), 1-7. http:// dx.doi.org/10.1590/0103-8478cr20151606.

Rodriguez-Amaya, D. B. (2001). A guide to carotenoid analysis in foods. Washington: International Life Sciences Institute.

Seddon, J. M., Ajani, U. A., Sperduto, R. D., Hiller, R., Blair, N., Burton, T. C., Farber, M. D., Gragoudas, E. S., Haller, J., Miller, D. T., Yannuzzi, L. A., \& Willett, W. (1994). Dietary carotenoids, vitamins A, C, and $\mathrm{E}$, and advanced age-related macular degeneration. Journal of the American Medical Association, 272(18), 1413-1420. http://dx.doi. org/10.1001/jama.1994.03520180037032. PMid:7933422.

Shami, N. J. I. E., \& Moreira, E. A. M. (2004). Lycopene as an antioxidant agent. Revista de Nutrição, 17(2), 227-236. http://dx.doi.org/10.1590/ S1415-52732004000200009.

Shao, A., \& Hathcock, J. N. (2006). Risk assessment for the carotenoids lutein and lycopene. Regulatory Toxicology and Pharmacology, 45(3), 289-298. http://dx.doi.org/10.1016/j.yrtph.2006.05.007. PMid:16814439.

Sobral, D., Bueno Costa, R. G., Machado, G. M., Jacinto de Paula, J. C., Martins Teodoro, V. A., Nunes, N. M., \& Pinto, M. S. (2016). Can lutein replace annatto in the manufacture of Prato cheese? Lebensmittel-Wissenschaft + Technologie, 68, 349-355. http://dx.doi. org/10.1016/j.lwt.2015.12.051.

Stringheta, P. C., Nachtigall, A. M., Maria, H., Sant, P., Paula, M., \& Conceição, J. (2006). Luteína: propriedades antioxidantes e benefícios à saúde. Alimentos e Nutrição, 17, 229-237.

Sumantran, V. N., Zhang, R., Lee, D. S., \& Wicha, M. S. (2000). Differential regulation of apoptosis in normal versus transformed mammary epithelium by lutein and retinoic acid. Cancer Epidemiology, Biomarkers \& Prevention, 9(3), 257-263. PMid:10750663.

Tamine, A. Y., \& Robinson, R. K. (2007). Yoghurt: science and technology (3rd ed.). New York: CRC Press.

Tokusoglu, O. (2013). The physicochemical, microbiological, organoleptic properties and antioxidant activities of functional cream cheeses fortified with lutein. International Journal of Dairy Technology, 66(4), 527-534. http://dx.doi.org/10.1111/1471-0307.12070.

Vargas, M., Cháfer, M., Albors, A., Chiralt, A., \& González-Martínez, C. (2008). Physicochemical and sensory characteristics of yoghurt produced from mixtures of cows' and goats' milk. International Dairy Journal, 18(12), 1146-1152. http://dx.doi.org/10.1016/j. idairyj.2008.06.007.

Vianna, F. S., Canto, A. C. V., Costa-Lima, B., Salim, A. P., Balthazar, C. F., Costa, M. P., Panzenhagen, P., Rachid, R., Franco, R. M., ConteJunior, C. A., \& Silva, A. C. O. (2019). Milk from different species on physicochemical and microstructural yoghurt properties. Ciência Rural, 49(6), 1-15. http://dx.doi.org/10.1590/0103-8478cr20180522.

Wang, C., Liu, J., Duan, B., Lao, Y. E., Qi, P. X., \& Ren, D. (2018). Effects of dietary antioxidant supplementation of feed, milk processing and storage on the lutein content and sensory quality of bovine milk. International Journal of Dairy Technology, 71(4), 849-856. http:// dx.doi.org/10.1111/1471-0307.12532.

Yildiz, E., \& Ozcan, T. (2019). Functional and textural properties of vegetable-fibre enriched yoghurt. International Journal of Dairy Technology, 72(2), 199-207. http://dx.doi.org/10.1111/1471-0307.12566.

Yildiz-Akgul, F. (2018). Enhancement of torba yoghurt with whey protein isolates. International Journal of Dairy Technology, 71(4), 898-905. http://dx.doi.org/10.1111/1471-0307.12525. 